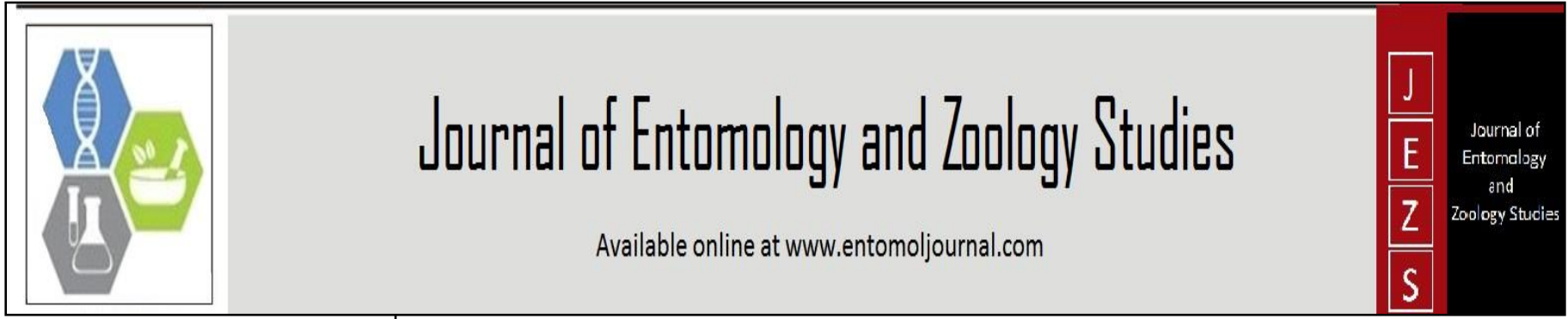

E-ISSN: 2320-7078

P-ISSN: 2349-6800

www.entomoljournal.com JEZS 2021; 9(2): 244-248 (C) 2021 JEZS

Received: 19-01-2021

Accepted: 21-02-2021

Raj Kumar

Assistant Professor,

School of Agriculture Science,

IIMT University, Meerut,

Uttar Pradesh, India

Nazim Ali

Professor and Head,

Dept. of Animal Husbandry,

SVPUAT, Meerut,

Uttar Pradesh, India

\section{RA Siddique}

Associate Professor,

Dept. of Veterinary Physiology

and Biochemistry, SVPUAT,

Meerut, Uttar Pradesh, India

DS Sahu

Associate Professor,

Dept. of Animal Husbandry,

SVPUAT, Meerut,

Uttar Pradesh, India

\section{Dr. Ahmad Fahim}

Assistant Professor, Dept. of

Livestock Production and

Management, SVPUAT, Meerut,

Uttar Pradesh, India.

Rajbir Singh

Dean, College of Veterinary and

Animal Science, SVPUAT,

Meerut, Uttar Pradesh, India

\section{Debashis Roy}

Associate Professor,

Dept. of Animal Nutrition,

SVPUAT, Meerut,

Uttar Pradesh, India
Corresponding Author:

Raj Kumar

Assistant Professor,

School of Agriculture Science,

IIMT University, Meerut,

Uttar Pradesh, India

\section{Effect of different levels of mushroom powder (Agaricus bisporus) and probiotics (Saccharomyces cerevisiae) on carcass traits and hematological responses of broiler chickens}

\author{
Raj Kumar, Nazim Ali, RA Siddique, DS Sahu, Dr. Ahmad Fahim, Rajbir \\ Singh and Debashis Roy
}

DOI: https://doi.org/10.22271/j.ento.2021.v9.i2d.8487

\section{Abstract}

A 42-day study was conducted to investigate the effect of mushroom powder (Agaricus bisporus) and probiotics (Saccharomyces cerevisiae) supplementation on carcass characteristics and breast meat quality in broiler chickens. 360 day-old broiler chicks were divided randomly into 8 dietary treatments with 3 replicates of 45 birds each in a completely randomized design. The experimental diets were designed as, $\mathrm{T}_{1}$ : control, $\mathrm{T}_{2}: 0.4 \%$ mushroom powder, $\mathrm{T}_{3}: 0.8 \%$ mushroom powder, $\mathrm{T}_{4}: 1.2 \%$ mushroom powder, $\mathrm{T}_{5}$ : $0.1 \%$ probiotics, $\mathrm{T}_{6}: 0.2 \%$ probiotics, $\mathrm{T}_{7}: 0.3 \%$ probiotics and $\mathrm{T}_{8}: 0.8 \%$ mushroom powder $+0.2 \%$ probiotics levels. The results showed that carcass parameters and prime cuts weights increased $(p<0.01)$ in birds fed probiotic and mushroom diets compared to control diets. Dressed weight was significantly $(P<0.01)$ higher for mushroom supplemented group $\mathrm{T}_{4}$ compared to the control group. Eviscerated weight was significantly $(P<0.01)$ higher in the mushroom supplemented group T8 compared to control group $\mathrm{T} 1$. The highest ready to cook yield percentage was observed in the combination of mushroom and probiotic supplemented group T8 compare to other groups. The highest abdominal fat was observed in the probiotics supplemented group ( $\left.\mathrm{T}_{8}\right)$ and the lowest noted in the control group. In conclusion, supplementation of mushroom powder and probiotics improved carcass traits, prime cut-parts and relative organ weights without any adverse effect on the blood parameters.

Keywords: broiler, carcass traits, feed, hematological, mushroom, probiotics

\section{Introduction}

Growth promoters are antibiotics that have been used to improve the performance of broiler chickens since its discovery near 1950. However, since 2006 the European Union banned the use of antibiotics as growth promoters in animal feed, and the use of alternative additives (non-antibiotics) has been increased (Huyghebaert et al 2011) ${ }^{[9]}$. In the last few decades, poultry has seen the greatest increase in production among most of the farm animal species and this trend is likely to continue shortly. Human population in India will rise at the rate of 61 $\%$ up to 2050 which is much more than the global average, resulting in social and economic changes, causing a great rise in chicken meat consumption in the country both overall and per person. According to the FAO (2012) the demand for poultry meat has consistently increased at around three times the rate of population growth over each of the past five decades. The high growth rate of the poultry industry is on account of its low capital investment, early assured returns, short generation intervals and limited land requirements. Today, it is a highly specialized, complex competitive business, characterized by phenomenal growth and has become one of the fastest growing segments of the agricultural sector in India. Statistical scenario shows a 2 percent increase per annum in the agricultural production during the last 30 years, while the rate of increase in the poultry sector has been dominant with the recent trend of 12 percent, as against the demand which is growing at over 15 per cent on the back of rising population.

Poultry meat is a very popular food commodity around the world due to its low cost of production as compared to meat products as beef, lamb or pork, low fat content, high nutritional value and distinct flavour (Barbut, 2002; Chouliara et al. 2007; Patsias et al. 2008) 
[3, 7, 19]. Processed meat product consumption has also dramatically increased over the last decades (Bianchi et al. 2009) ${ }^{[5]}$. Food safety is an important aspect of food quality and efforts should be led to the safety of new functional products from poultry meat (Burdock et al. 2006) ${ }^{[6]}$. Meat quality may be affected already by manipulation of animal feeding (Kennedy et al. 2005; Assi and King, 2007) ${ }^{[14,2]}$ or post mortem manipulation of carcass body. Meat quality is one of the economically important traits in chicken. Poultry meat is an important source of high quality proteins, minerals and vitamins to balance the human diet. Specially developed varieties of chicken (broilers) are now available with the traits of quick growth and high feed conversion efficiency. Depending on the farm size, broiler farming can be the main source of family income or can provide subsidiary income and gainful employment to farmers throughout the year. Poultry manure is of high fertilizer value which can be used for increasing yield of all crops add the aim of the present study.

\section{Material and Methods}

The experiment was conducted at the Poultry Research and Training Center under the Department of Animal Husbandry, Sardar Vallabhbhai Patel University of Agriculture \& Technology, Modipuram, Meerut-250110. A total of 360 day old chicks were weighed and allocated to 8 dietary treatments with 3 replications of 45 birds each in a completely randomized design. Standard feed was prepared and used throughout the experimental study. Composition of the experimental starter and finisher diets fed to broilers and proximate composition of starter and finisher feeds of broilers are shown in (Table $1 \&$ 2). Cross mixing was applied during the time of mixing. Mixing was done manually and no coccidiostat or any other feed additives were added to the formulated diets to get a clear-cut effect of the test-diet. Mushroom powder and probiotics were added to the experimental diets (except control diet) at required amount according to each treatment. The chicks were provided feed according to their requirements as per the NRC, 2001 specifications. At the end of the experiment, two birds whose weights close to the mean replicate weight were selected from each replicate, fasted overnight, weighed, slaughtered, scalded in $65^{\circ} \mathrm{C}$ water for 15 seconds, manually defeathered and eviscerated. Thereafter, the carcasses were dissected; the prime cut-up parts were removed and weighed together with the visceral organs and were expressed as percentage live weight. Two $\mathrm{mL}$ blood was collected for hematological analysis through jugular veins of two birds of similar weights from each replicate into sterilized glass tubes containing EDTA. The PCV was determined by microhematocrit method (Schalm et al., 1975) ${ }^{[23]}$. Mean Corpuscular Volume (MCV), Mean Corpuscular Hemoglobin $(\mathrm{MCH})$ and Mean Corpuscular Hemoglobin Concentration (MCHC) were calculated from $\mathrm{Hb}, \mathrm{PCV}$ and erythrocyte concentration of blood (RBC) (Jain, 1986) ${ }^{[10]}$.

\section{Results and Discussion \\ Carcass composition}

The results for different carcass traits measured under various treatment groups have been presented in Tables $3 \& 4$. The results show that all treatment groups were significantly $(P<0.01)$ differed higher than control group. The highest slaughter weight was observed in mushroom supplement group $\left(T_{4}\right)$ and the lowest was for control group $\left(T_{1}\right)$. These results were equally in harmony with the finding of Kabir et al. (2004) ${ }^{[11]}$ who reported the occurrence of a significantly $(P<0.01)$ higher carcass yield in broiler chicks fed with the probiotics on the $2^{\text {nd }}, 4^{\text {th }}$ and $6^{\text {th }}$ week of age both in vaccinated and nonvaccinated birds. Onifade et al. (1999b) ${ }^{[18]}$ reported that yeast culture supplementation increased carcass weight and carcass yield compared to control group $(P<0.01)$. Eviscerated weight was significantly $(P<0.01)$ higher in the mushroom supplemented group T8 compared to control group $\mathrm{T} 1$. There were no significant difference $(\mathrm{P}>0.01)$ among mushroom supplemented group $\left(\mathrm{T}_{2}\right)$ and probiotics supplemented groups $\left(\mathrm{T}_{5} \& \mathrm{~T}_{7}\right)$ as well as among mushroom supplemented group $\left(\mathrm{T}_{4}\right)$, probiotics supplemented group $\left(\mathrm{T}_{6}\right)$. This observation agrees with the earlier reports of Savage et al. (1985) [22] concluded that live yeast culture supplementation reduced the fat content of female turkeys. In the present study the highest breast weight, thigh weight, neck weight and drumstick weight were significantly $(P<0.01)$ differed with control group. The highest back weight was observed in the probiotics supplemented group $\left(\mathrm{T}_{7}\right)$ and the lowest back weight recorded in the control group $\left(\mathrm{T}_{1}\right)$. These results were equally in harmony with the finding of Pelicano et al. (2003) ${ }^{[20]}$ showed a significantly decreased $(P<0.01)$ carcass weight from birds fed a diet with probiotics compared to the control diet. The study of Roshanfekr and Mamooee (2009) ${ }^{[21]}$ on broilers showed significantly high $(P<0.01)$ breast muscle weight from the broilers fed a diet with $0.2 \%$ commercial probiotics at the age of 42 days. In a study conducted by Mohan et al. (1996) ${ }^{[16]}$ on broilers, it was found that carcass weight of broiler significantly affected $(P<0.05)$ breast meat yield. As well as carcass weight and yield of the broilers that were fed with diet containing Saccharomyces cerevisiae produced higher breast meat. In the present experiment gizzard weight was significantly higher in treatment groups as compared to control group. These results were equally in harmony with the finding of Koc et al. (2010) [15] mentioned broilers fed direct SC gave less $(P<0.01)$ gizzard weight compared to broilers fed SC absent diet. Interestingly, results obtained from the current study also showed, broilers fed the SC incorporated diet for long term had less $(P<0.01)$ gizzard weight compared to broilers fed SC for short term. Behrouz et al. (2012) ${ }^{[4]}$ reported that weights of gizzard, liver and bursa of fabricius were not affected significantly by addition of prebiotics, probiotics and antibiotics because low diet was given to the broiler compared to our experiment.

\section{Hematological parameters}

It was observed that mushroom (Agricus bisporus) and probiotics $(S C)$ supplementation enhanced hematological parameters present in Table 5. The hematologies of the groups of pullets supplemented with probiotics were higher compared to the control. On the final day of the experiment the hematological parameters observed, RBC, HGB, WBC $\left(10^{3} / \mu \mathrm{l}\right)$, haemoglobin concentration, haemoglobin $(\mathrm{Hb})$ concentration, packed cell volume (PCV), were significantly increased $(P<0.01)$ in the treated groups than the control group. The mean corpuscular volume (fl), MCH (pg), MCHC $(\mathrm{g} / \mathrm{dl})$ were decreased significantly $(P<0.01)$ than the control group. The different values of hematological parameters remained within the normal range but statistically significant within the comparison of the treated and the control groups. According to Khaksefidi and Ghoorchi (2006) [13] when poultry diets are supplemented with probiotics, the 
hematological profile showed an increase in total erythrocyte and leukocyte cell count and a marked increase in percentage of lymphocytes. This increase in total erythrocyte, leukocyte cell count and lymphocyte count was probably due to the stimulation of the immune system of pullets leading to increase in TLC and lymphocyte proliferation (Aathouri et al, 2001) [1] caused by the probiotics. Probiotics effect on lymphocytes count was highly demonstrated at the hematological determination carried out at the peak of egg lay where all the supplemented groups had significantly $(P<0.01)$ higher lymphocyte counts than the control. This immunostimulatory effect may help to increase the pullets' resistance to infections. The present study is in agreement with earlier report by Naidu et al. (1999) ${ }^{[17]}$ who revealed that the inclusion of yeast increased the number of $\mathrm{T}$ lymphocytes, antibody secreting cells, natural killer cell activity and enhanced lymphocyte proliferation. The broiler chicks in group $\mathrm{T}_{4}$ (MP 1.2\%) showed a significant higher packed-cell volume (\%) level with all other treated groups when compared to the control group. These results were equally in harmony with the finding of the hematological parameters of the present finding resembles that of Dukes et al.(1955) ${ }^{[8]}$ who reported that the number of erythrocytes and other components of blood varied due to the influence of age, sex, environment, exercise, nutritional status and climate. With regard to the influence of probiotic on hematological parameters, there were an only significant increase in RBCs count, hemoglobin and PCV in mushroom and Saccharomyces cerevisiae fed broilers. These results were found by Karoglu and Drudag (2005) ${ }^{[12]}$, who found that adding a probiotics diet, could inhibit the nutritional stress in broiler chickens.

Table 1: Composition of the experimental starter and finisher diets fed to broilers

\begin{tabular}{|c|c|c|c|c|}
\hline \multirow{2}{*}{ S.N. } & \multirow{2}{*}{ Feed ingredients } & \multicolumn{3}{|c|}{ Amount (kg/100kg feed) } \\
\cline { 3 - 5 } & Maize & Pre-Starter (1 to 14days) & Starter (15 to 27days) & Finisher (28 to 42days) \\
\hline 1 & 36.00 & 37.00 & 39.00 \\
\hline 2 & Rice Polish & 34.00 & 35.00 & 38.00 \\
\hline 3 & Soybean Meal & 9.00 & 9.00 & 7.00 \\
\hline 4 & Groundnut Cake & 9.00 & 8.00 & 7.00 \\
\hline 5 & Fish Meal & 9.00 & 8.00 & 6.00 \\
\hline 6 & Mineral Mixture & 2.00 & 2.00 & 2.00 \\
\hline 7 & Common Salt & 1.00 & 1.00 & 1.00 \\
\hline & Total & 100.0 & 100.0 & 100.0 \\
\hline
\end{tabular}

Table 2: Proximate composition of Starter and finisher feeds

\begin{tabular}{|c|c|c|c|c|}
\hline S. No. & Chemical constituents & Pre Starter feed & Starter feed & Finisher feed \\
\hline 1. & Moisture & 10.01 & 10.40 & 9.80 \\
\hline 2. & Dry Matter & 89.99 & 89.60 & 90.20 \\
\hline 3. & Ash & 6.59 & 5.20 & 5.38 \\
\hline 4. & Organic Matter & 93.41 & 94.80 & 94.62 \\
\hline 5. & Crude Protein & 22.75 & 22.50 & 20.00 \\
\hline 6. & Ether Extract & 4.36 & 4.75 & 4.851 \\
\hline 7. & Calcium & 0.96 & 0.98 & 0.97 \\
\hline 8 & Phosphorus & 0.65 & 0.45 & 0.40 \\
\hline 9 & Metabolisable Energy $(\mathrm{Kcal} / \mathrm{Kg})$ & 3250 & 2810 & 2890 \\
\hline
\end{tabular}

Table 3: Carcass traits and prime-cut parts of broilers fed different levels of mushroom powder and probiotics supplementation

\begin{tabular}{|c|c|c|c|c|c|c|c|c|c|c|}
\hline \multirow{2}{*}{ Parameters } & \multicolumn{10}{|c|}{ Treatments } \\
\hline & $T_{1}$ & $\mathbf{T}_{2}$ & $\mathbf{T}_{3}$ & $\mathbf{T}_{4}$ & $\mathbf{T}_{5}$ & $T_{6}$ & $\mathbf{T}_{7}$ & $\mathbf{T}_{8}$ & SEM & P-value \\
\hline Pre- slaughter wt (g) & $1815.00^{\mathrm{a}}$ & $1852.50^{\mathrm{ab}}$ & $1930.00^{\text {cde }}$ & $1983.75^{\mathrm{e}}$ & $1883.00^{\mathrm{bc}}$ & $1951.50^{\mathrm{de}}$ & $1915.00^{\mathrm{bcd}}$ & $1972.75^{\mathrm{de}}$ & 13.65 & $<0.01$ \\
\hline Dressing wt (g) & $1288.75^{\mathrm{a}}$ & $1338.75^{\mathrm{b}}$ & $1395.50^{c}$ & $1445.50^{\mathrm{d}}$ & $1346.25^{\mathrm{bc}}$ & $1394.75^{\mathrm{c}}$ & $1373.50^{\mathrm{cd}}$ & $1441.25^{\mathrm{d}}$ & 6.75 & $<0.01$ \\
\hline Dressing wt (\%) & $71.01^{\mathrm{a}}$ & $72.27^{\mathrm{abc}}$ & $72.31^{\mathrm{abc}}$ & $72.87^{\mathrm{bc}}$ & $71.50^{\mathrm{ab}}$ & $71.48^{\mathrm{ab}}$ & $71.74^{\mathrm{abc}}$ & $73.06^{\mathrm{d}}$ & 0.33 & $<0.01$ \\
\hline Eviscerated wt (\%) & $59.94^{\mathrm{a}}$ & $61.34^{\mathrm{abc}}$ & $62.07^{\mathrm{bc}}$ & $62.42^{\mathrm{c}}$ & $60.32^{\mathrm{ab}}$ & $61.60^{\mathrm{abc}}$ & $61.12^{\mathrm{abc}}$ & $62.81^{\mathrm{c}}$ & 0.41 & $<0.01$ \\
\hline Drumstick (\%) & $10.16^{\mathrm{e}}$ & $10.02^{\mathrm{de}}$ & $9.68^{\mathrm{abc}}$ & $9.45^{\mathrm{ab}}$ & $9.87^{\text {cde }}$ & $9.57^{\mathrm{abc}}$ & $9.75^{\mathrm{bc}}$ & $9.41^{\mathrm{a}}$ & 0.07 & $<0.01$ \\
\hline Thigh $\mathrm{Wt}(\%)$ & $18.51^{\mathrm{e}}$ & $17.85^{\mathrm{d}}$ & $17.05^{\mathrm{bc}}$ & $16.51^{\mathrm{ab}}$ & $17.88^{\mathrm{d}}$ & $16.97^{\mathrm{ab}}$ & $17.52^{\mathrm{cd}}$ & $16.49^{\mathrm{a}}$ & 0.12 & $<0.01$ \\
\hline Breast wt (\%) & $33.58^{\mathrm{ab}}$ & $33.41^{\mathrm{ab}}$ & $33.06^{\mathrm{ab}}$ & $32.23^{\mathrm{ab}}$ & $33.66^{\mathrm{ab}}$ & $32.52^{\mathrm{ab}}$ & $33.80^{\mathrm{b}}$ & $31.95^{\mathrm{a}}$ & 0.37 & $<0.01$ \\
\hline Back wt (\%) & $22.51^{\mathrm{a}}$ & $22.92^{\mathrm{ab}}$ & $23.81^{\mathrm{b}}$ & $23.32^{\mathrm{ab}}$ & $23.77^{\mathrm{b}}$ & $23.60^{\mathrm{b}}$ & $25.29^{c}$ & $23.19^{\mathrm{ab}}$ & 0.21 & $<0.01$ \\
\hline Neck $(\%)$ & $3.15^{\mathrm{a}}$ & $3.18^{\mathrm{ab}}$ & $3.26^{\mathrm{ab}}$ & $3.31^{\mathrm{bcd}}$ & $3.41^{\mathrm{d}}$ & $3.34^{\mathrm{cd}}$ & $3.29^{\mathrm{bcd}}$ & $3.35^{\mathrm{cd}}$ & 0.03 & $<0.01$ \\
\hline
\end{tabular}

A,b,c Means with different superscripts within the same column are significantly different $(P<0.01)$; SEM: Standarderror of mean. Treatment:

$\mathrm{T}_{1}($ control $)=$ not supplemented; $\mathrm{T}_{2}=0.4$ percent Mushroom powder; $\mathrm{T}_{3}=0.8$ percent Mushroom powder; $\mathrm{T}_{4}=1.2$ percent mushroom powder; $\mathrm{T}_{5}=0.1$ percent Probiotics, $\mathrm{T}_{6}=0.2$ percent Probiotics, $\mathrm{T} 7=0.3$ percent Probiotics and $\mathrm{T} 8=0.8$ per cent Mushroom powder +0.2 percent Probiotics

Table 4: Effects of feeding different levels of mushroom and probiotics on organs proportional parameter of broiler chicks

\begin{tabular}{|c|c|c|c|c|c|c|c|c|c|c|}
\hline \multirow{2}{*}{ Parameters } & \multicolumn{10}{|c|}{ Treatments } \\
\hline & $T_{1}$ & $\mathbf{T}_{2}$ & $\mathbf{T}_{3}$ & $\mathbf{T}_{4}$ & $T_{5}$ & $T_{6}$ & $\mathbf{T}_{7}$ & $\mathbf{T}_{8}$ & SEM & P-value \\
\hline Gizzard wt (\%) & $1.87^{\mathrm{ab}}$ & $1.98^{\mathrm{b}}$ & $2.00^{\mathrm{b}}$ & $1.94^{\mathrm{ab}}$ & $1.85^{\mathrm{ab}}$ & $1.87^{\mathrm{ab}}$ & $1.80^{\mathrm{a}}$ & $1.99^{\mathrm{b}}$ & 0.04 & $<0.01$ \\
\hline Heart weight (\%) & $0.49^{\mathrm{a}}$ & $0.51^{\mathrm{abc}}$ & $0.54^{\mathrm{d}}$ & $0.56^{\mathrm{ds}}$ & $0.50^{\mathrm{ab}}$ & $0.54^{\text {cd }}$ & $0.55^{\mathrm{d}}$ & $0.53^{\text {bcd }}$ & 0.01 & $<0.01$ \\
\hline Proventicular wt (\%) & $0.411^{\mathrm{a}}$ & $0.436^{\mathrm{ab}}$ & $0.477^{\mathrm{bc}}$ & $0.537^{\mathrm{d}}$ & $0.543^{\mathrm{d}}$ & $0.507^{\mathrm{cd}}$ & $0.529^{\mathrm{cd}}$ & $0.535^{\mathrm{d}}$ & 0.01 & $<0.01$ \\
\hline Liver wt (\%) & $2.24^{\mathrm{ab}}$ & $2.35^{\mathrm{bc}}$ & $2.28^{\mathrm{abc}}$ & $2.22^{\mathrm{a}}$ & $2.39^{\mathrm{c}}$ & $2.36^{\mathrm{bc}}$ & $2.40^{\mathrm{c}}$ & $2.32^{\mathrm{abc}}$ & 0.03 & $<0.01$ \\
\hline
\end{tabular}

A,b,c Means with different superscripts within the same column are significantly different $(P<0.01)$; SEM: Standarderror of mean. Treatment:

$\mathrm{T}_{1}($ control $)=$ not supplemented; $\mathrm{T}_{2}=0.4$ percent Mushroom powder; $\mathrm{T}_{3}=0.8$ percent Mushroom powder; $\mathrm{T}_{4}=1.2$ percent mushroom powder; $\mathrm{T}_{5}=0.1$ percent Probiotics, $\mathrm{T}_{6}=0.2$ percent Probiotics, $\mathrm{T} 7=0.3$ percent Probiotics and $\mathrm{T} 8=0.8$ per cent Mushroom powder +0.2 percent Probiotics 
Table 5: Hematological traits of broiler chicks fed diets supplemented with different levels of mushroom and probiotics

\begin{tabular}{|c|c|c|c|c|c|c|c|c|c|c|}
\hline \multirow{2}{*}{ Hematological parameters } & \multicolumn{10}{|c|}{ Treatments } \\
\hline & $\mathbf{T}_{1}$ & $\mathbf{T}_{2}$ & $\mathbf{T}_{3}$ & $\mathbf{T}_{4}$ & $\mathbf{T}_{5}$ & $T_{6}$ & $\mathbf{T}_{7}$ & $T_{8}$ & SEM & P-value \\
\hline RBC (million cell//mm³) & $2.45^{\mathrm{a}}$ & $2.61^{\mathrm{b}}$ & $2.78^{\mathrm{cd}}$ & $3.01^{\mathrm{ef}}$ & $2.73^{\mathrm{bc}}$ & $2.91^{\mathrm{de}}$ & $3.05^{\mathrm{f}}$ & $2.89^{\mathrm{de}}$ & 0.03 & $<0.01$ \\
\hline $\mathrm{WBC}\left(10^{3} / \mu \mathrm{l}\right)$ & $41.63^{\mathrm{a}}$ & $41.93^{\mathrm{a}}$ & $42.75^{\mathrm{bc}}$ & $43.53^{\mathrm{cd}}$ & $42.33^{\mathrm{ab}}$ & $43.33^{\mathrm{c}}$ & $44.31^{\mathrm{de}}$ & $44.63^{\mathrm{e}}$ & 0.17 & $<0.01$ \\
\hline Haemoglobin $(\mathrm{g} / \mathrm{dl})$ & $11.60^{\mathrm{a}}$ & $11.98^{\mathrm{b}}$ & $12.41^{\mathrm{c}}$ & $13.12^{\mathrm{d}}$ & $12.46^{\mathrm{c}}$ & $12.60^{\mathrm{c}}$ & $13.12^{\mathrm{d}}$ & $12.92^{\mathrm{d}}$ & 0.05 & $<0.01$ \\
\hline Packed-cell volume (\%) & $28.21^{\mathrm{a}}$ & $29.50^{\mathrm{b}}$ & $31.92^{\mathrm{d}}$ & $33.32^{\mathrm{e}}$ & $30.78^{\mathrm{c}}$ & $31.91^{\mathrm{d}}$ & $32.10^{\mathrm{d}}$ & $32.90^{\mathrm{de}}$ & 0.22 & $<0.01$ \\
\hline $\mathrm{MCV}(\mathrm{fl})$ & $115.36^{\mathrm{d}}$ & $112.85^{\mathrm{bcd}}$ & $114.88^{\mathrm{cd}}$ & $110.71^{\mathrm{bc}}$ & $112.84^{\mathrm{bcd}}$ & $109.81^{\mathrm{ab}}$ & $105.43^{\mathrm{a}}$ & $114.20^{\mathrm{bcd}}$ & 0.96 & $<0.01$ \\
\hline $\mathrm{MCH}(\mathrm{pg})$ & $47.44^{\mathrm{c}}$ & $45.82^{\mathrm{bc}}$ & $44.65^{\mathrm{ab}}$ & $43.59^{a}$ & $45.67^{\mathrm{bc}}$ & $43.34^{\mathrm{a}}$ & $43.12^{\mathrm{a}}$ & $44.86^{\mathrm{ab}}$ & 0.46 & $<0.01$ \\
\hline $\mathrm{MCHC}(\mathrm{g} / \mathrm{dl})$ & $42.06^{\mathrm{c}}$ & $40.30^{\mathrm{ab}}$ & $39.64^{\mathrm{ab}}$ & $38.96^{\mathrm{a}}$ & $40.70^{\mathrm{bc}}$ & $39.29^{\mathrm{ab}}$ & $40.50^{\mathrm{abc}}$ & $39.59^{\mathrm{ab}}$ & 0.35 & $<0.01$ \\
\hline
\end{tabular}

a,b,c Means with different superscripts within the same column are significantly different $(P<0.01)$; SEM Standard error of mean. Treatment: T 1 $($ control $)=$ not supplemented $\mathrm{T}_{2}=0.4$ percent Mushroom powder; $\mathrm{T}_{3}=0.8$ percent Mushroom powder; $\mathrm{T}_{4}=1.2$ percent mushroom powder; $\mathrm{T}_{5}=$ 0.1 percent Probiotics, $\mathrm{T}_{6}=0.2$ percent Probiotics, T7 $=0.3$ percent Probiotics and T $8=0.8$ per cent Mushroom powder +0.2 percent Probiotics

\section{Conclusion}

Broilers ration supplemented with mushroom powder (Agaricus bisporus) and probiotics (Saccharomyces cerevisiae) revealed significant improvement in different carcass traits like pre-slaughter weight, dressing weight, drumstick and gizzard weight, liver weight etc. and haematogical traits like RBC, WBC, PVC, $\mathrm{Hg}$, and $\mathrm{MCH}$ of broiler meat. This indicates that the supplementation of mushroom powder and probiotics improved the carcass quality traits of broiler and the values of different hematological parameters were found in the normal range in all supplemented group without any adverse effects

\section{Acknowledgement}

The authors acknowledge the hon'ble Vice Chancellor, Sardar Vallabhbhai Patel University of Agriculture \& Technology, Modipuram, Meerut-250110 India, for providing the funds required for this study.

\section{References}

1. Aathouri N, Bouras M, Tome D, Marcos A, Lemonnier D. Oral ingestion of lactic acid bacteria by rats increases lymphocyte proliferation and interferon production. British Journal of Nutrition 2001;87:367-373.

2. Assi JA, King AJ. Assessment of selected antioxidants in tomato pomace subsequent to treatment with the edible oyster mushroom, Pleurotus ostreatus, under solid-state fermentation. Journal of Agricultural and Food Chemistry 2007;55:9095-9098.

3. Barbut S. Poultry products processing. An industry guides (1st Ed.). London: CRC Press, 2002, 548.

4. Behrouz RD, Sajjad H, Afshin Z. Effect of dietary supplementations of prebiotics, probiotics, synbiotics and acidifiers on growth performance and organs weight of broiler chickens. European Journal of Experimental Biology 2012;2(6):2125-2129.

5. Bianchi M, Ferioli F, Petracci M, Caboni M, Cavani C. The influence of dietary lipid source on quality characteristics of raw and processed chicken meat. European Food Research and Technology 2009;229:339348.

6. Burdock GA, Carabin IG, Griffiths JC. The importance of GRAS to the functional food and nutraceutical industries. Toxicology 2006;1:17-27.

7. Chouliara E, Karatapanis A, Savvaidis I, Kontominas M G. Combined effect of oregano oil and modified atmosphere packaging on shelf-life extension of fresh chicken breast meat, stored at $4{ }^{\circ} \mathrm{C}$. Food Microbiology 2007;24:607-617.

8. Dukes HH. The physiology of domestic animals, 7th Edition, Baillers Tindal and Co. London 1955, 96-98.
9. Huyghebaert G, Ducatelle R, Van Immerseel F. An update on alternatives to antimicrobial growth promoters for broilers. Veterinary Journal 2011;187;182-188.

10. Jain NC. Schalm's Veterinary Hematology. 4thEdn. Lea and Febrigen, Philadelphia, USA 1986, 34-50.

11. Kabir SML, Rahman MM, Rahman MB, Rahman MM, Ahmed SU. The dynamics of probiotics on growth performance and immune response in broilers. International Journal of Poultry Science 2004;3:361-364.

12. Karoglu M, Durdag H. The influence of dietary probiotic (Saccharomyces cerevisiae) supplementation and different slaughter age on the performance, slaughter and carcass properties of broiler. International Journal of Poultry Science 2005;4:309-316.

13. Khaksefidi A, Ghoorchi T. Effect of probiotics on performance and immune competence in broiler chicks. Journal of Poultry Science 2006;43:296-300.

14. Kennedy OB, Stewart-Knox BJ, Mitchell PC, Thurnham DI. Vitamin E supplementation, cereal feed type and consumer sensory perceptions of poultry meat quality. British Journal of Nutrition 2005;93:333-338.

15. Koc H, Samli A, Okur M, Ozduven HA, Senkoylu N. Effects of Saccharomyces cerevisiae and/or Mannan oligosaccharide on performance, Blood parameters and intestinal microbiota of broiler chicks. Bulgarian Journal of Agricultural Science 2010;16:643-650.

16. Mohan B, Kadirvel R, Natarjan A, Bhaskaran M. Effect of probiotics supplementation on growth, nitrogen utilization and serum cholesterol in broilers. British Poultry Science 1996;37:395-401.

17. Naidu AS, Bidlack WR, Clemens RA. Probiotics spectra of lactic acid bacteria (LAB). Critical Reviews in Food Science and Nutrition 1999;39:13-126.

18. Onifade AA, Odunsi AA, Babatunde GM, Olorede BR, Muma E. Comparison of the supplemental effects of Saccharomyces cerevisiae and antibiotics in low-protein and high-fiber diets fed to broiler chicken. Archive of Animal Nutrition 1999b; 52:29-39.

19. Patsias A, Badeka AV, Savvaidis IN and Kontominas MG. Combined effect of freeze chilling and MAP on quality parameters of raw chicken fillets. Food Microbiology 2008;25:575-581.

20. Pelicano ERL, Souza PAD, Souza HBADe, OA, Norkus EA, Kodawara LM, Lima TMAD. Effect of different probiotics on broiler carcass and meat quality. Revista Brasileira de Ciência Avícola 2003;5:207-214.

21. Roshanfekr H, Mamooee M. Effect of dietary antibiotic, probiotic and prebiotic as growth promoters, on growth performance, carcass characteristics and hematological indices of broiler chickens. Pakistan Journal of Biological Sciences 2009;12:52-57. 
22. Savage TF, Nakaue HS, Holmes ZA. Effects of feeding live yeast culture on market turkey performance and cooked meat characteristics. Nutrition Reports International 1985;3:695-703

23. Schalm JW, Jain NC, Carol EJ. Veterinary Hematology. $3^{\text {rd }}$ Edn. Lea and Febriger. Philadelphia USA 1975, 1581 . 